\title{
MENINGKATKAN MOTIVASI BELAJAR SISWA DENGAN METODE NUMBERED HEADS TOGETHER (NHT) PADA PELAJARAN IPA DI KELAS IV SD NEGERI 026609 BINJAI
}

\author{
Masta Ginting, Indra Maulana \\ * Dosen Jurusan PPSD Prodi PGSD FIP UNIMED \\ ** Mahasiswa Jurusan PPSD Prodi PGSD FIP UNIMED \\ Surel : Indramaulana014@gmail.com
}

\begin{abstract}
Abstrak
Penelitian ini dilaksanakan di kelas IV SD Negeri 026609 Binjai yang bertujuan untuk meningkatkan motivasi belajar siswa dengan metode pembelajaran Numbered Heads Together (NHT) pada materi pokok energi panas dan energi bunyi. Penelitian yang dilakukan adalah penelitian tindakan kelas (Classroom Action Research). Teknik pengumpulan data yang digunakan adalah menggunakan lembar observasi dan angket. Peningkatan rata-rata motivasi belajar siswa untuk tiap siklus, pada kondisi awal skor motivasi belajar siswa dari 35 orang siswa, yang termotivasi adalah 4 orang dengan persentase $(11,42 \%)$, dan skor motivasi belajar siswa pada siklus I pertemuan I meningkat menjadi 11 orang siswa termotivasi dengan persentase $(31,42 \%)$, dan terjadi peningkatan pada siklus I pertemuan II yaitu 18 orang siswa termotivasi dengan persentas $(51,43 \%)$, dan juga terjadi peningkatan pada siklus II pertemuan I yaitu 26 orang siswa termotivasi dengan persentase $(74,29 \%)$, dan terjadi yang signifikan pada siklus II pertemuan yaitu 34 orang siswa termotivasi dengan persentase $(97,15 \%)$.
\end{abstract}

Kata Kunci : Model, Numbered Heads Together, Classroom Action Research

\section{PENDAHULUAN}

Pendidikan adalah suatu proses dalam rangka mempengaruhi siswa agar dapat menyesuaikan diri sebaik mungkin terhadap lingkungannya dan dengan demikian akan menimbulkan perubahan dalam dirinya yang memungkinkannya untuk berfungsi dalam kehidupan bermasyarakat serta hal yang sangat penting untuk membekali siswa menghadapi masa depannya.

IPA merupakan salah satu mata pelajaran yang wajib dipelajari diberbagai jenjang pendidikan seperti SD, SMP dan SMA. IPA merupakan ilmu pengetahuan yang berhubungan dengan kejadian-kejadian benda dan berdasarkan pada hasil pengamatan dan percobaan disekitar kita. Membahas dan mempelajari IPA tidak cukup hanya mentransfer apa yang ada di buku teks kepada peserta didik. Karena apa yang terdapat dalam buku teks itu baru merupakan satu sisi atau satu dimensi saja dari IPA yaitu dimensi "produk", yang telah tersusun secara lengkap dan sistematis. Buku teks memang penting tetapi ada sisi lain dari IPA yang tidak kalah pentingnya ialah dimensi "proses", maksudnya proses mendapatkan ilmu itu sendiri. Serta diharapkan juga pembelajaran Ilmu 
Pengetahuan Alam dapat menjadi wahana bagi siswa untuk mempelajari diri sendiri dan alam sekitar, serta prospek pengembangan lebih lanjut dalam penerapannya didalam kehidupan sehari-hari.

IPA diperoleh melalui penelitian dengan menggunakan langkah-langkah tertentu yang disebut metode ilmiah. Tentu saja anak SD tidak diajarkan bagaimana membuat suatu penelitian secara lengkap tetapi dapat mulai diperkenalkan secara bertahap, misalnya melakukan pengamatan dengan cermat. Kemudian melaporkan hasil pengamatannya kepada rekan-rekan sekelasnya. Sebagai upaya tahap pertama, dimensi proses ini justru sangat penting dalam menunjang proses perkembangan anak didik secara utuh karena dapat melibatkan segenap aspek psikologi anak yang meliputi kognitif, efekti, dan psikomotor. Melalui dimensi proses ini peserta didik memperoleh kemampuan untuk menggali sendiri pengetahuan yang ada dari alam sekitar. Sehingga peserta didik senantiasa bisa belajar apapun, kapanpun dan dimana pun sesuka hatinya. Kesimpulannya adalah proses pembelajaran IPA menekankan pada pemberian pengalaman langsung untuk mengembangkan kompetensi agar diarahkan untuk berbuat sehingga dapat membantu siswa untuk memperoleh pengalaman yang lebih mendalam tentang alam sekitar.
Berdasarkan observasi dan pengalaman penulis ketika kegiatan PPL, penulis melihat ketika guru mengajar masi terfokus hanya pada buku pelajaran, guru hanya menjelaskan apa yang ada pada buku dan menyuruh siswa untuk mencatat serta menghafal apa yang ada di dalam buku pelajaran. Peneliti juga menemukan sebahagian dari siswa tidak hadir dikarenakan malas dengan mata pelajaran IPA. Adapun data ketidak hadiran siswa pada saat pelajaran IPA yang peneliti dapatkan tiap minggunya yaitu berjumlah 8 orang dari 35 orang. Mengapa demikian, karena Mata pelajaran IPA itu hanya ada 4 kali dalam satu minggu, jadi dalam satu hari ada 2 orang siswa tidak hadir pada mata pelajaran IPA. Kemungkinan juga faktor lainnya guru tidak mengajak siswa untuk memanfaatkan fasilitas kelas dan alam yang ada di sekitar sekolah sehingga siswa kurang aktif dalam proses pembelajaran dan siswa kurang termotivasi untuk belajar IPA. Banyak siswa yang malas dan mengantuk ketika belajar IPA raut wajah siswa terlihat seperti tidak semangat ketika memasuki jam pelajaran IPA. Akan tetapi bukan berarti sepenuhnya penulis menilai semua permasalahan ini dikarenakan oleh guru, mungkin saja guru banyak kegiatannya selain mengajar sehingga guru tidak sempat menggunakan berbagai variasi dalam pembelajaran.

Motivasi belajar siswa erat kaitanya dengan kemampuan guru dalam proses pembelajaran. 
Kemampuan guru dalam menggunakan metode atau model pembelajaran yang tepat tentunya akan mengaktifkan siswa dalam belajar. Sehingga dapat memotivasi siswa untuk dapat belajar secara mandiri tanpa harus diperintah oleh orang lain. Dengan demikian siswa akan belajar secara mandiri tanpa harus diperintah oleh orang lain. Dengan demikian siswa akan belajar dengan penuh semangat. Oleh karena itu guru hendaknya mampu memotivasi siswa agar memiliki semangat belajar yang tinggi. Misalnya menjelaskan materi pelajaran dengan menggunakan contoh - contoh yang kongkrit, sesuai dengan pengalaman siswa, dan mengajak siswa untuk ikut mempraktikkan sendiri, melakukan pengamatan, melakukan diskusi sehingga kemampuan intelektual siswa, sikap, minat dan kreatifitas siswa menjadi meningkat.

Rendahnya motivasi belajar siswa pada pembelajaran IPA disebabkan oleh rendahnya kualiatas pembelajaran yang diselenggarakan guru serta kurang efektifnya metode pembelajaran yang digunakan guru dalam menjelaskan materi pembelajaran. Menurut hasil wawancara dengan kepala sekolah SD Negeri 026609 Binjai Selatan, kecenderungan motivasi belajar siswa terhadap pelajaran IPA tergolong rendah. Hal ini disebabkan karena kurang efektifnya metode pembelajaran yang digunakan guru dalam mengembangkan proses belajar mengajar kurang bervariasi sehingga siswa hanya memperhatikan penjelasan guru dan sedikit sekali melibatkan siswa untuk berinteraksi dengan siswa lainya. Bentuk pembelajaran IPA masih didominasi guru dengan menggunakan metode ceramah dan jarang mengunakan melakukan kerja kelompok. Sehingga aktivitas siswa hanya mendengarkan penjelasan guru dan mencatat hal-hal yang dianggap penting. Dengan demikian pemilihan metode pembelajaran yang tepat dan efektif sangat diperlukan. Agar siswa dapat belajar secara efektif dan efesien tidak terfokus menghafal saja maka guru haru menggunakan metode pembelajaran yang sesuai dengan tujuan yang diharapkan.

Salah satu metode pembelajaran yang akan dilakaukan serta diharapkan untuk memperbaiki permasalahan yang ada dalam penelitian ini adalah dengan menggunakan metode pembelajaran Numbered Heads Together (NHT). Metode pembelajaran ini sebagai alternatif untuk membawa siswa belajar IPA dalam suasana yang lebih nyaman dan menyenagkan. Siswa akan lebih bebas dan kompak dalam menemukan berbagai pengalaman baru dalam belajarnya seperti belajar menjalin kerjasama, menghargai pendapat teman dan belajar bermusyawarah untuk memecahkan persoalan sehingga diharapkan dapat tumbuh berbagai kegiatan belajar siswa. Lebih dari itu, metode pembelajaran ini menjadikan pengajaran dan pembelajaran lebih 
menggairahkan. Peneliti merasa yakin bahwa metode pembelajaran ini cocok untuk diterapkan dalam proses pembelajaran IPA di SD. Lingkungan yang mendukungdan proses pembelajaran yang menyenangkan dan menggairahkan dapat menciptakan serta meningkatkan motiva sisiswa SD untuk belajar IPA. Sehingga keluhan-keluhan seperti bosan, jenuh, kurang bergairah dan tidak menarik yang selama ini sering dikatakan siswa dalam proses pembelajaran IPA dapat teratasi dan tentunya melalui metode Numbered Heads Together (NHT) ini diharapkan dapat meningkatkan motivasi siswa dalam proses pembelajaran IPA.

Setelah peneliti mempelajari metode Numbered Heads Together (NHT), penulis menganggap bahwa metode Numbered Heads Together (NHT) ini sesuai untuk mengajarkan Pelajaran IPA kepada siswa, karena banyak menuntut kemampuan berfikir siswa, juga guru dalam memotivasi serta mengarahkan siswa untuk menemukan konsep dasar IPA yang benar serta mampu juga mengaplikasikannya dalam kehidupan sehari-hari.

Berdasarkan uraian dari latar belakang diatas, maka dapat diidentifikasi penyebab motivasi belajar siswa rendah, yaitu sebagai berikut:

a. Rendahnya motivasi belajar siswa, khususnya pada mata pelajaran IPA. b. Siswa kurang aktif ketika proses pembelajran IPA.

c. Metode pembelajran yang diterapkan kurang bervariasi dan kurang efektif dalam pembelajaran IPA.

d. Siswa hanya terfokus pada teknik menghafal dalam belajar IPA.

e. Kurangnya pengelolaan kelas dan penggunaan fasilitas yang dilakukan dalam pelaksanaan pembelajaran.

Adapun yang menjadi rumusan masalah dalam penelitian ini adalah: "Apakah Dengan Metode Numbered Heads Together (NHT) Dapat Meningkatkan Motivasi Belajar Siswa Pada Mata Pelajaran IPA Dengan Materi Energi Dan Penggunaanya Terkhusus Materi Pokok Energi Panas Dan Energi Bunyi Pada Siswa Kelas IV SD Negeri 026609 Binjai T.A 2014/2015 ?".

Adapun tujuan penelitian ini adalah: "Untuk Meningkatkan Motivasi Belajar Siswa Pada Mata Pelajaran IPA Dengan Materi Energi Dan Penggunaanya Terkhusus Materi Pokok Energi Panas Dan Energi Bunyi Melalui Metode Numbered Heads Together (NHT) Pada Siswa Kelas IV SD Negeri 026609 Binjai T.A 2014/2015".

a. Bagi Siswa diharapkan siswa termotivasi dalam belajar khususnya pada pelajaran IPA dengan menggunakan metode 
pembelajaran Numbered Heads

Together (NHT).

b. Bagi Guru sebagai bahan masukan bagi guru SD, khususnya guru SD Negeri 026609 Binjai untuk memotivasi belajar siswa kelas IV pada mata pelajaran IPA melalui penerapan metode pembelajaran Numbered Heads Together (NHT).

c. Bagi sekolah sebagai bahan kajian dan reverensi dalam mengajar guru di sekolah untuk meningkatkan Motivasi belajar siswa dengan menggunakan metode pembelajaran Numbered Heads Together (NHT).

d. Bagi Peneliti dan Peneliti Lain sebagai bahan reverensi peneliti dan mahasiswa PGSD lainnya mengenai penerapan metode pembelajaran Numbered Heads Together (NHT) untuk meningkatkan motivasi belajar siswa SD kelas IV. Bagi peneliti lain sebagai bahan masukan, dan referensi dalam mengembangkan keterampilan mengajar bagi mahasiswa calon guru lainnya dalam membuat penelitian.

\section{METODOLOGI PENELITIAN}

Jenis penelitian ini adalah Penelitian Tindakan Kelas (classroom action research), atau biasa disebut dengan PTK. Dengan menggunakan metode Numbered
Heads Together sebagai metode mengajar yang utama. Dimana penelitian ini berupa Penerapan metode Numbered Heads Together untuk meningkatkan motivasi belajar siswa pada mata Pelajaran IPA di kelas IV SD Negeri 026609 Binjai T.A 2014/2015. Penelitian ini bertujuan untuk memperbaiki proses pembelajaran dalam meningkatkan motivasi belajar siswa. Dalam penelitian ini hanya menggunakan satu kelas saja.

\section{Subjek Penelitian}

Subjek dalam penelitian tindakan kelas ini adalah siswa/i kelas IV SD Negeri 026609 Binjai Selatan. Objek dalam penelitian ini adalah metode Numbered Heads Together.

\section{Desain Penelitian}

Rancangan penelitian yang akan digunakan mengacu pada metode yang dikembangkan oleh Kemmis dan Mc. Taggart (Rosmala Dewi, 2010 :122). Secara garis besar terdapat empat tahapan yang dilaksanakan penelitian tindakan kelas, yaitu: "1. Perencanaan, 2. Tindakan, 3. Observasi, 4. Refleksi”. Untuk lebih jelasnya, desain penelitian dapat digambarkan pada skema berikut:

\section{Teknik Pengumpulan Data}

Alat yang digunakan dalam pengumpulan data penelitian ini adalah berupa instrumen untuk mencatat semua aktivitas siswa selama tindakan berlangsung. Alat 
pengumpulan data yang digunakan yaitu :

a. Lembar observasi

Observasi merupakan salah satu cara untuk mengumpulkan data penelitian. Observasi diartiakan sebagai pengamatan dan pencatatan secara sistematis terhadap gejala yang tampak pada objek penelitian. Lembar Observasi digunakan untuk mengopservasi kegiatan siswa da guru. Observasi dilakukan 4 kali dalam dua siklus. 2 kali di siklus I dan 2 kali di siklus II. Pengumpulan data melalui observasi dibantu oleh guru kelas dan teman sejawat penelitib, pada kelas yang dijadikan sebagai subjek penelitian untuk mendapatkan gambaran secara langsung kegiatan belajar dikelas.

b. Observasi dilakukan pada saat proses belajar mengajar dengan menggunakan pedoman observasi kegiatan pembelajaran, catatan lapangan, dan foto, dengan tujuan memperoleh data tentang proses penggunaan metode Numbered Heads Together pada pelajaran IPA. Instrumen observasi, catatan lapangan, dan foto digunakan untuk menuliskan hasil penelitian.

c. Angket

Angket merupakan data penunjang yang digunakan untuk mengumpulkan informasi terkait dengan respon atau tanggapan siswa terhadap motivasi siswa yang dilakukan 2 kali yaitu di awal siklus I dan diakhir siklus II.

\section{Teknik Analisis Data}

Analisis data ini dilakukan untuk mengetahui peningkatan motivasi belajar siswa dengan metode pembelajran Numbered Heads Together untuk mengetahui berhasil tidaknya tindakan yang dilakukan. Kriteria untuk menentukan peningkatan dari hasil motivasi belajar siswa, antara lain dengan rumus:

Motivasi belajar $=\frac{\text { Skor yang diperoleh }}{\text { Skor maksimum }} \times 100$ (Purwanto 2011:207)

80-100 Motivasi belajar siswa Tinggi 60-79 Motivasi belajar siswa Cukup 0-59 Motivasi belajar siswa Kurang

Dalam penelitian ini, target kategori yang ingin dicapai oleh peneliti dalam meningkatkan motivasi belajar siswa adalah kategori motivasi belajar Tinggi, dengan jumlah skor $80 \%$ - $100 \%$ dari jumlah siswa.

a. Kriteria untuk menentukan angket belajar siswa manggunakan rumusan :

PPA $=\frac{B}{N} X 100 \% \quad$ menurut Sukardi (2008:147)

Keterangan :

PPA $=$ Persentase pemulai angket

$\mathrm{B}=$ Skor angket

$\mathrm{N}=$ Skor total (Dalam

Sukardi, 2008:147)

b. Untuk mengukur tingkat motivasi belajar siswa secara 
klasikal digunakan rumus sebagai berikut :

$\mathrm{P}=\frac{f}{n} x 100 \%$

Keterangan :

$\mathrm{P}=$ Angka motivasi.

$\mathrm{f}=$ Jumlah siswa yang mengalami perubahan

$\mathrm{n}=$ Jumlah seluruh siswa.

(dalam Dewi 2010 :335 )

\section{Indikator Keberhasilan Tindakan}

Untuk mengetahui apakah tindakan yang dilakukan dalam penelitian berhasil atau tidak, maka peneliti menyusun beberapa indikator ketercapaian sebagai berikut:

Minimal $\quad 80 \% \quad$ siswa termotivasi belajarnya meningkat secara klasikal pada mata pelajaran IPA dengan materi energi dan penggunaanya terkhusus materi pokok energi panas dan energi bunyi.

\section{HASIL PENELITIAN DAN PEMBAHASAN}

Penelitian ini dilakukan di SD Negeri 026609 Binjai Selatan, Jalan. Sei Babalan Pujidadi Kecamatan Binjai Selatan di kelas IV semester genap tahun ajaran 2014/2015, yang berjumlah 20 orang siswa laki-laki dan 15 orang siswa perempuan. Selama penelitian berlangsung kehadiran siswa diupayakan 100\%, agar tidak mempengaruhi hasil penelitian. Langkah pertama yang dilakukan oleh peneliti adalah memberikan surat izin pelaksanaan penelitian kepada kepala sekolah, dan melakukan indentifikasi dan observasi di SD Negeri 026609 Binjai Selatan, Jalan. Sei Babalan Pujidadi Kecamatan Binjai Selatan terhadap masalah yang akan diteliti dengan melakukan kegiatan pengamatan terhadap perilaku siswa. Selain itu peneliti juga mengamati cara belajar yang dilakukan oleh guru dan melihat situasi di lingkungan sekolah.

Penelitian dilakukan pada saat siswa berada di kelas dengan menggunakan alat bantu yang berupa lembar observasi motivasi belajar siswa dan angket untuk melihat gejala motivasi belajar siswa di kelas seperti perilaku belajar siswa yang di antaranya adalah tekun dan ulet menghadapi tugas, menunjukan minat tinggi, mandiri, dapat mempertahankan pendapatnya dan teguh pendirian, bekerja sama dalam mencari dan memecahkan masalah soal-soal, eginvolment, hasrat untuk belajar. Kelas yang diobservasi adalah siswa kelas IV SD Negeri 026609 Binjai, Selatan Jalan. Sei Babalan Pujidadi Kecamatan Binjai Selatan dengan menggunakan lembar observasi dan angket, berdasarkan lembar observasi dari setiap pernyataan dan indikator yang ditetapkan, dan angket yang telah diisi oleh siswa hampir rata- rata siswa memiliki motivasi belajar dengan kriteria kurang, hal ini dapat dilihat berdasarkan hasil obeservasi yang dilakukan oleh peneliti di kelas IV SD Negeri 026609 Binjai, Selatan 
Jalan. Sei Babalan Pujidadi Kecamatan Binjai Selatan, bahwa sebagian besar siswa kurang memiliki motivasi dalam pelajaran IPA pada materi pokok energi panas dan energi bunyi.

\section{SIKLUS I}

Berdasarkan hasil observasi pada siklus I, maka peneliti melakukan refleksi terhadap seluruh kegiatan pada siklus I. Hanya sebagian siswa yang mau berpartisipasi dalam pembelajaran, hal itu terlihat dari hanya sebagian siswa yang mau bekerja sama dalam berdiskusi kelompok.

Siswa masih terkesan bingung dalam sistem pembelajaran yang digunakan oleh guru. Dalam hal ini guru memberikan arahan dan pemahaman kepada siswa tentang langkah-langkah pembelajaran yang sedang digunakan.

Siswa masih belum berani untuk mengungkapkan pendapatnya, siswa masih cenderung diam dan sulit berkomunikasi. Siswa masih tunjuk-tunjukkan dengan temannya ketika guru menyuruh siswa untuk mempersentasikan hasil diskusinya di depan kelas. Dalam hal ini guru kurang membuat variasi pembelajaran yang sesuai dengan pemahaman siswa dan inovasi pembelajaran yang lebih menyenangkan.

Hal ini diperkuat dengan data yang diperoleh berdasarkan hasil observasi pada siklus I. Hasil observasi motivasi belajar siswa pada siklus I pertemuan I motivasi belajar siswa hanya $(31,42 \%)$ siswa yang Termotivasi dan pada pertemuan II motivasi belajar siswa mengalami sedikit kenaikan yaitu $(51,43 \%)$. Kriteria ini masih tergolong Kurang dan belum sesuai dengan harapan.

Dengan perincian pada pertemuan I 11 orang siswa $(31,42 \%)$ memperoleh kriteria Tinggi, 10 orang siswa $(28,57 \%)$ memperoleh kriteria Cukup, dan 14 orang siswa (40\%) memperoleh kriteria Kurang. Dan pada pertemuan II 18 orang siswa $(51,43 \%)$ memperoleh kriteria Tinggi, 4 orang siswa $(11,43 \%)$ memperoleh kriteria Cukup, dan 13 orang siswa (37.14\%) memperoleh kriteria Kurang. Dan melalui data penyebaran angket pada siklus I terdapat hanya 15 orang siswa dengan persentase $(42,86 \%)$ yang Termotivasi dengan kriteria Tinggi pada pelajaran sains, dengan perolehan nilai angket lebih dari 80 , dan 12 orang siswa dengan persentase $\quad(34,29 \%) \quad$ Tidak Termotivasi pada pelajaran sains dengan kriteria Cukup dan perolehan nilai angket kurang dari 80, dan 8 orang siswa dengan persentase $(22,85 \%)$ juga Tidak Termotivasi pada mata pelajaran sains dengan kriteria Kurang dengan perolehan nilai angket kurang dari 80 .

Dengan demikian pada pelaksanaan siklus II perlu adanya inovasi dari tahapan model pembelajaran Numbered Heads Together (NHT) yang dapat mendorong siswa lebih aktif dan termotivasi. 


\section{SIKLUS II}

Berdasarkan hasil siklus II, dalam hal refleksi peneliti bersama guru kelas IV SD Negeri 026609 Binjai Selatan Jalan. Sei Babalan Pujidadi Kecamatan Binjai Selatan berkumpul untuk melakukan refleksi tindakan yang telah dilaksanakan oleh peneliti. Dari hasil pengamatan tindakan yang dilaksanakan peneliti dari berbagai aspek motivasi belajar siswa menunjukkan adanya peningkatan yang signifikan. Dengan demikian, pada siklus II kegiatan pembelajaran yang dilakukan dipandang sudah cukup dan tidak perlu dilanjutkan pada siklus berikutnya.

Hasil observasi motivasi belajar siswa pada siklus II pertemuan I masih tergolong Cukup yaitu 26 orang siswa $(74,29 \%)$ yang memperoleh krtiteria Tinggi, 1 orang siswa $(2,86 \%)$ yang memperoleh kriteria Cukup, dan 8 orang siswa $(22,85 \%)$ yang mendapat kriteria Kurang. Dan Hasil observasi motivasi belajar siswa pada siklus II pertemuan II sudah tergolong Tinggi yaitu $(97,15 \%)$. Kriteria ini sudah sesuai dengan harapan dan tidak perlu dilanjutkan pada siklus berikutnya, dengan perincian 34 orang siswa $(97,15 \%)$. Termotivasi dalam belajar dengan kriteria Tinggi, dan 1 orang siswa $(2,86 \%)$ Tidak termotivasi dalam belajar dengan memperoleh kriteria Cukup. Dan melalui data penyebaran angket bahwa 32 orang siswa dengan persentase $\quad(91,43 \%) \quad$ yang Termotivasi dengan kriteria Tinggi pada pelajaran Sains, dengan perolehan nilai angket lebih dari 80, dan 3 orang siswa dengan persentase $(8,57 \%)$ Tidak Termotivasi pada pelajaran sains dengan kriteria Cukup dan perolehan nilai angket kurang dari 80.

Dengan demikian dapat dinyatakan bahwa motivasi belajar siswa meningkat dalam pelajaran Sains materi energi panas dan energi bunyi dengan menerapkan metode pembelajaran Numbered Heads Together (NHT).

\section{SIMPULAN DAN SARAN}

Berdasarkan hasil penelitian dan kesimpulan diatas, dapat dikemukakan beberapa saran, yaitu:

a. Disarankan guru di SD diharapkan melakukan pengajaran dengan menggunakan metode pembelajaran Numbered Heads Together (NHT) sebagai alternativ dalam kegiatan pembelajaran karena metode pembelajaran Numbered Heads Together (NHT) dapat meningkatkan motivasi belajar siswa serta untuk melatih siswa belajar aktif.

b. Siswa diharapkan lebih bersemangat dalam belajar dan diharapkan mau berkomunikasi dengan baik, 
baik kepada guru maupun teman.

c. Hendaknya diawal pembelajaran guru selalu memberikan motivasi dengan cara pemberian pujian agar siswa lebih percaya diri dan semangat dalam mengikuti pelajaran di kelas.

d. Disarankan pula agar menerapkan motode pembelajaran Numbered Heads Together (NHT) bukan hanya dalam matapelajaran IPA melainkan juga pada pelajaran lain

\section{DAFTAR PUSTAKA}

A.M, Sardiman. 2011. Interaksi dan Motivasi Belajar Mengajar. Jakarta:

Raja Wali Pers 2011.

Dewi, Rosmala. 2010. Penelitian Tindakan Kelas. Medan: Pasca Sarjana Unimed.

Dimyati dan Mudjiono. 2013. Belajar dan Pembelajaran. Jakarta: Rineka Cipta.

Hamzah, B. Uno. 2012. Belajar dengan Pendekatan Paikem. Jakarta: Bumi Aksara.

Huda, Miftahul. 2010. Cooperative Learning Metode, Teknik, Struktur dan Model
Penerapan. Jakarta: Bumi Aksara 2010.

Istarani. 2012. Model Pembelajaran Inovatif. Medan: Media Persada.

Ismaliah, Dewi. 2008. Ilmu Pengetahuan Alam. Bandung: Yrama Widya, 2008.

Lie, Anita. 2002. Cooperative Learning

Memperaktikan Cooperative

Learning Di Ruang Kelas, Jakarta: PT. Grasindo 2002.

Slameto. 2010. Belajar dan FaktorFaktor yang Mempengaruhinya. Jakarta: Rhineka Cipta.

Suprijono, Agus. 2009. Cooperative Learning Teori \& Aplikasi PAIKEM. Yogyakarta: Pustaka Pelajar 2009.

Trianto. 2009. Mendesain Model Pembelajaran InovatifProgresif Tingkaat Satuan Pendidikan (KTSP). Jakarta: Kencana 2010.

Warsito. 2010. Buku Panduan Belajar Mahir Menguasai RPAL (SAINS). Surabaya: Mahir Sindo Utama. 